\title{
The Accessory Penalties for Individuals and their Execution According to the Albanian Legislation
}

\author{
Skerdian Kurti \\ Faculty of Law, University of Tirana, Albania
}

Doi:10.5901/ajis.2015.v4n2p505

\begin{abstract}
Additional penalties, means the type of punishments that may be awarded by the Court against those guilty, as a rule together with major penalties. Accessory penalties can be viewed in two perspectives: the mitigation of punishment if the court with the fulfilment of certain conditions set just giving punishments; the intensification of punishment the court alongside the main sentence gives and punishment in order to realize more fully the purpose of punishment. The goal of treatment of this topic is the most complete knowledge of punishments considering the achievements and the need for changes in terms of criminal justice and for a more efficient operation in the implementation and establishment of an appropriate system for control over their implementation in practice.
\end{abstract}

Keywords: Albanian legislation, criminal law, the principal penalty, accessory penalties, the execution of sentences, jurisprudence.

\section{Introduction}

The road towards improving the future passes through the recognition and evolution of the past. For this reason we present below a brief picture of the punishments prescribed in criminal codes that are implemented in different periods which passed Albanian criminal law.

So in the Criminal Code of Zogu (Gjilani, 2001, 387) additional punishments have these types: article 25 (confiscation of property), article 27 (loss of rights), article 28 (loss of electoral law), article 29 (removal of honorary titles and decorations), article 30 (prohibition to state or social duties assigned), article 31 (loss of the right to retirement), article 32 (loss of parental rights), article 33 (prohibition of carrying out a specific activity).

In 1952 the Criminal Code came into force built according to models Eastern countries and based on the policy of the ruling party to lead and guide the entire life of the country (Elezi, 1972, 3). Additional penalties provided for this code were the same as those provided by Code of Zogu.

Later, in 1977 the Criminal Code came into effect, which was more closed than the previous code in terms of contemporary orientations of criminal law (Elezi, 1968, 21). In this code envisioned these kinds of additional punishments: article 23 (removal of honorary titles and decorations), article 24 (abolition of the right to vote), article 26 (deportation), article 27 (deportation). There is a difference in the number of punishments towards their reduction compared to the previous codes.

\section{Additional Penalties in Criminal Code of 1995}

The Albanian criminal code came into force with the law nr.7491, dated 31.5.1995. Given that in this period the criminal and legal opinion began to unload from political influence, the analysis of the causes of crime and punishment policy underwent significant changes. Gradually begin to appear opinions and more consolidated as such abolition of the death penalty (The death penalty was provided by the criminal codes years 1928, 1952, 1977) and replacing it with life imprisonment, the introduction of new measures of punishment etc.

Even in the new criminal code, from a structural standpoint, maintaining the traditional form, that of the classification of sentences in two groups: group of sentences in major penalties for persons who have committed crimes and grouping the main penalties for persons who have committed offences. Likewise are grouped and additional penalties for persons who have committed various offences. This code provides the following additional penalties: a) the prohibition of the right to exercise public functions; b) confiscation of assets the offence and the proceeds of crime; $c$ ) prohibition on driving; d) removal of decorations, honorary titles; e) removal of the right to exercise a profession or skill; f) removal of the right to undertake leading to juridical persons; g) prohibition to stay in one or more administrative units; $h$ ) 
expulsion from the territory; i) the obligation to publish the court; j) loss of parental responsibility.

There is an increase in the types of punishments. In this penal code compared to the previous, although we almost identical structure of the system of penalties no more talk of species such criminal penalties socialist character as punishment re-education through labour or social reprimand.

As amended by law nr.9086, dated 19.06.2003 and nr.9275 dated 16.09.2004 article 35 has changed, being called the "abolition of the right to exercise public functions" while ago called "deprivation of the right to exercise state functions". So is expanding the concept. This change is not formal. It has effects on implementation, as the circle of persons to whom it may apply additional measure expands.

All punishments, as a rule are given along with the main sentence. However under-priority paragraph of article 30 of the criminal code, the Court, in exceptional cases, when giving punishments deemed to be inappropriate and when the law provides for imprisonment up to 3 years or other penalties easier for the offence committed, can decide only the supplementary sentence.

Prediction of this possibility of implementing additional sentence instead of the main sentence, is another phenomenon of liberalization of punishment in the criminal code.

By the law nr.23, dated 01.03.2012 "Amendments and additions to the Criminal Code", article 30 is added to the content item 10 "Loss of parental responsibility" and after article 43 added to article 43/a with this content "Loss of parental responsibility given by the court against a person who exercises parental responsibility when he is sentenced as author or accomplice in an offence against a child or as a collaborator with the child in the commission of a criminal offence".

\section{Explanation of Additional Penalties and Judicial Practice Issues}

a) Deprivation of the right to exercise public functions. On top of punishments is the removal of the right to exercise public functions (Elezi \& al., 2009, 215). This kind of punishment implies that the person who committed the offence, the Court's decision removed the right to exercise public functions. Deprivation of the right to exercise public functions may be given for a period to be determined by the Court's decision. Thus, removal of the right to exercise public functions, for a period not less than five years, must be given to the person who has committed a crime related to the task, by abusing the public office or has committed a crime for which court imposed a sentence of imprisonment of not less than ten years. While under the second paragraph of article 35 of the criminal code, the court has imposed a sentence of five to ten years, in addition to his sentence can implement the removal of the right to exercise public functions for a period of three to five years, and the Court has imposed a sentence of up to three years in prison, this sentence can be given for a period of one to three years. When punishment is given together with the penalty of imprisonment, its implementation begins after the person has served a prison sentence.

b) Confiscation of assets the offence and the proceeds of crime. For the first time, along with additional new penalties foreseen the punishment of confiscation of the proceeds of the offence in article 36 of the criminal code (Elezi \& al., 2009, 217). In previous codes, this kind of punishment was provided only as a procedural, which dealt with the decision by the investigating body, and eventually to uphold its resolve Court in its final decision. Through the changes made in 2003 (The law nr.9086, dated 19.06.2003, has changed article 36 of the criminal code), the legislator has provided in paragraph 2 of article 36 of the criminal code to include not only the seizure of the means of committing the offence, but also the products derived from the commission of the offence. The purpose of this add-on is to combat organized crime, and especially economic. He must be given to the court and consists of reception and transfer to the state of things that have served or are given as means to commit a criminal act, the products of any property, document or legal instrument that proves executive titles, reward, database or promised, as well as any other property, the value of which corresponds to that of the proceeds of crime, items, production, possession and use of which constitute a criminal offence (With the changes made to this section by law nr.9086, dated 19.06.2003, the circle of objects that can be seized is expanding). Given that the offence products often transformed, cleansed and transformed into other assets, the criminal code allows for the confiscation of them, even when it is united with real estate acquired legally. In this case the rate of seizures is up to the value of proceeds of crime. Subject to confiscation are also income or other benefits from the products of the offence, transformed or converted.

c) Prohibition on driving. The punishment provided for in article 37 of the criminal code, finds wide support and implementation in practice. This provision of the criminal code has specific purpose educational and 
preventative. The ban on driving given by the Court for a time from one to five years, and implemented after the main penitentiary sentence. According to the content of article 37, it appears that this sentence can be given to the principal punishment to persons who have committed a criminal offense, when considered appropriate by the Court that he would have a preventive effect, or agree with the nature of the offense, especially with the consequences of income.

d) Removal of decorations and titles. According to the first paragraph of article 38 of the criminal code, it is understood that the removal of decorations and honorary titles is mandatory or optional measure that can be taken or not by the court for persons who have committed a criminal offence punishable by imprisonment. The court in this case considers that keeping decorations and honorary titles agrees or not with the nature of the offence committed. So for example for offences against morality and dignity, for theft and fraud, smuggling, abuse of office may be granted by the court such a sentence.

In the second paragraph provided that the removal of decorations and honorary titles is permanent when a person convicted of a crime over 10 years imprisonment, while the person is sentenced to ten years imprisonment imposed by the court as a measure of one to five years.

e) Deprivation of the right to exercise an activity or trade. Deprivation of the right to exercise an activity or skill may be granted by the Court as punishment, banning convicted of carrying out the activity or workmanship for which was given special permission, authorization, or license from the state competent authority. This kind of punishment is optional and left to the price of the Court, which accordingly can give or not this kind of punishment, as to persons who are employed by the State and to those who exercise private subject only to have embezzled it. Granted for a period from one month to five years

f) Deprivation of the right to exercise managerial duties. This punishment is provided in article 40 of the criminal code (By law nr.9275, dated 16.09.2004, Article 40 is added a third paragraph ). If the court gives such a penalty, director, administrator or developer does not have the right to exercise these functions, or any other task that has to do with the quality of the representatives of the legal person.

This punishment is for a limited time, from one month to five years and by the third paragraph for a period of five to ten years, when it was condemned by the Court not less than five years in prison, more offences which the convict has abused charged or has acted contrary to the rules relating to the duty charged by these persons.

g) Prohibition to stay in one or more administrative units. From the content of article 41 of the criminal code observed that in a moderate way is restored punishment of expulsion (Punishment of expulsion envisaged in the previous penal codes as: code of Zogu (article 22); 1952, criminal code (article 22); 1977, criminal code (article 26). Criminal code of 1995, this sentence comes with another formulation.), the previous criminal code but with another formulation. Prohibition to stay in one or more administrative units given by the Court when it considers that the attitude of the perpetrator who has committed a criminal offense in one or several specific administrative unit is dangerous to society. This is potentially dangerous, because the attitude of the guilty in this or that administrative units deemed that creates opportunities for committing offenses other via links, recognition or friendship that may have with other people. This punishment is given by the court for a time from one to five years, as a rule against those persons who have been convicted of theft, smuggling, drug abuse, public disorder, etc. When the sentence is given together with the penalty of imprisonment, its implementation begins after the person has served a prison sentence.

h) Expulsion from the territory. The article 42 of the criminal code also include one kind of deportation (This kind of punishment for foreigners or stateless who commit crimes in the Republic of Albania has been provided in previous codes $(1928,1952,1977)$ in the provision of deportation ) for people with foreign citizenship or stateless who commit crimes, taking it expulsion from the territory of the Republic of Albania.

Expulsion from the territory is the feature that distinguishes from that provided in article 41 of the criminal code:

- First, extraction placed outside the Republic of Albania and not limitation of residence in one or more administrative units.

- Secondly, expulsion from the territory of the Republic of Albania decided by the Court only to foreign nationals or stateless persons and never to Albanian citizens.

- Thirdly, this kind of punishment is given to foreign nationals or stateless persons, who have committed crimes and criminal offences, deemed that their further stay in the Republic of Albania should not continue on in the future. 
According to the last paragraph of article 42 , when the foreign citizen or stateless, acquires Albanian citizenship under the law, his request is the same court that issued revoke his decision outside the territory. When the sentence is given together with the penalty of imprisonment, its implementation begins after the person has served a prison sentence.

i) The publication of the judicial decision. This is a sentence that is provided for the first time in the system of penalties in section 43 of the criminal code. With this sentence, the convict is obliged to make known its spending more on mass media content in full or in part of a judgment given by the Court. This obligation shall be determined Court in its judgment set and term of this publication. The court also determines the date of publication. Publication is granted when deemed that have to do with certain circumstances the law itself mentions in its content. These circumstances deem appropriate by the Court.

j) Loss of parental responsibility (Parental responsibility includes the entirety of the rights and duties that are intended to ensure emotional, social and material of the child, caring for, keeping personal relations, ensuring proper growth, education, legal representation and administration of his estate.). From the content of article $43 / a$ of the criminal code shows that in a moderate way is restored punishment of loss of parental rights, the previous criminal code (code of Zogu and the criminal code of 1952), but the other formulation (Code of Zogu and the criminal code of 1952 predicted the loss of parental rights to this content: "The court may decide the loss of parental rights of prisoners only when he sees that he has abused those rights. Loss of parental rights granted for a period of one to five years".).

The Court decided the loss of parental responsibility to the person who carries it when he punished as the author or accomplice in an offence against a child or as collaborators with the child in the commission of an offence.

Parental responsibility provided as such in article 215 of the family code. There are two terms that uses the family code in respect of parental responsibility: a) loss of parental responsibility (Article 223 of the family code); b) removal of this responsibility (Article 228 of the family code).

Loss of parental responsibility is the result when the perpetrator of a criminal act directed against the child shall be punished. In this case he loses parental responsibility. While the removal of parental responsibility is provided in a separate provision of the family code, article 228 (When the parent abuses parental responsibility or shows negligent in its exercise, or his actions adversely affects a child's upbringing, at the request of the other parent, the child's relatives or the prosecutor may be removed parental responsibility. The removal of parental responsibility made by the court, citing as Indicted parent, which requires such removal.). Removal of parental responsibility can ask relatives of the child, but may also require the prosecutor.

Setting this punishment comes bearing in mind the situation in Albanian legislation, Albania's obligations under the conventions ratified. The purpose of this sentence is to protect the interest of the child.

In November 2010 we adopted a law to protect the rights of the child. In this law have provided special protection of children's rights and has a chapter which deals with the care that can be provided to a child. I mention this law, because having this law and the establishment of mechanisms for the protection of children in the local and national level gives the opportunity to resolve concerns in practice alternative care for children.

There will be difficulties in implementation in practice of this punishment by the court. The difficulty that confronts a criminal court is that it will have to adjust to the consequences and the need to determine where the child should stay and which is the most convenient arrangement for the child, something a criminal court cannot make it to the end of a criminal trial. The court will punish the offender, then the parent, and with the main sentence will give punishment. Here ends the work of a criminal court. How to deal with the solution of further consequences, because it may be one or more children? Normally, the Court should investigate for children, for their condition. This is not regulated procedure codes and will lead to an inability or these kids will fix just in decisions, but will not be adjusted in nature. So changes needed for enforcement of the code of criminal procedure.

\section{Execution of Accessory Penalties}

Under article 468 of the criminal procedure code, for the execution of punishments prosecutor sends shortening the sentence judicial police bodies and other interested bodies (Kurti, 2014, 153). While under article 34 of the law nr.8331, dated 21.04.1998 "On Execution of Penal Sentences" amended (EPS), the main punishment was given, together with the executed and punishments prescribed by paragraphs 2, 4 and 9 article 30 of the criminal code. Additional penalties executed after the main penitentiary.

Prohibition of the exercise of state duties (article 41 EPS - Article 35 of the criminal code which provides for this 
measure, was redesigned by article 5 of the law nr.9275, dated 16.09.2004, while article 41 of the law "On execution of court decisions" has remained unchanged. Consequently we have two different names of the measure). Punishment of prohibition to exercise state functions or public service, implemented by the body that appointed or who has entered the convict labour relations, with the dismissal of relevant, respecting the legislation. When the employment relationship is created by choice, the decision is executed by competent authority. When public service assignments conditional on licensing, executed by the decision to grant the license.

Execution of sentence confiscation (article 40 EPS). Criminal decisions that predict forfeiture of benefits derived from the offence, applied by the competent execution under the provisions of the code of civil procedure for compulsory execution. The bailiff in the execution of the decision is not limited to objects seized, but all facilities and benefits clearly defined in the Court's decision (Hysi, 2012, 147).

Prohibition on driving (article 37 EPS). For additional execution of sentence on driving prohibition under article 37 EPS, police authorities withdraw convicted order as long as the evidence has established the Court. Police rule turns the ability testimony before the deadline fixed by order of the prosecutor or other competent authorities, as provided by special law.

Removing the decorations or the securities (article 36 EPS). For decisions that contain punishment of removal of decorations and honorary titles, the prosecutor sends the execution order has granted authority to award or title and copy of the decision, asking to be related records, badges and sign the withdrawal of testimony original by the convict. When because of decoration or title privileges or benefits, the abovementioned notify relevant authorities for their termination.

Prohibition of the exercise of an activity or skill (article 42 EPS). Removing the possibility of exercising the profession accomplished by the removal of a license or permit granted and executed by the body that has given permission or license. For the prosecutor issue of the writ and sends the body that has given the license or permit. The latter informs the financial authorities of the decision taken by the Court.

Deprivation of the right to exercise managerial duties (article 43 EPS). This penalty shall be executed by the body that has such a right under the statute or the relevant rules and notify the competent financial.

Prohibition of residence (article 38 EPS). Order executed by police order, which takes measures to prevent the entry of prisoners in a unit or its removal from the unit is found. To achieve the implementation of this measure police have the right to make inspections or take other actions defined in the law, which enable the person seeking forbidden territories. The law provides for the establishment of facilities for the convict who is a single parent and minor child. In such a case, to accommodate child custody charged the council.

Expulsion from the territory (article 39 EPS). The sentence extraction outside the convict executed by the deadline set by the prosecutor in the order of execution, on the contrary rules of compulsory execution. When the inmate has been the main jail sentence, extraction outside the prison police executed immediately upon completion of the main penitentiary. When the convicted person cannot return to the country whose citizen is either in another state, the prosecutor is obliged to provide access to his land or visa, otherwise submits a request to change the punishment. In any case for foreign nationals convicted through the Ministry of Justice prosecutor informed the Ministry of Foreign Affairs to order the execution of the sentence.

Obligation to publish the decision (article 44 EPS). In the execution of this decision, the Prosecutor shall make available the full text convicted or its extract as determined by the court. The convict is obliged to publish, at its own expense, in one or several media outlets in the time and manner specified in the decision and, when there are obstacles, requiring the intervention of the prosecutor. When the body is expressly stated by the Court, argues for reasonable cause or publication in the body is impossible, the prosecutor asks the Court to amend the decision, otherwise the prosecutor determines its own method of publishing.

\section{Conclusions}

At the conclusion of this paper can reach some conclusions regarding punishments. We said that as a rule punishments given together with key sentences. However in the last paragraph of Article 30 of the Criminal Code made an exception to the application of additional punishment itself.

Forecast such a space legislator has limited the competition of two conditions:

- The first condition is taxation, so that the criminal offence provided for a sentence of no more than three years in prison;

- The second condition is entirely in the subjectivity of the panel, which has a duty to ascertain that the granting of only one punishment will achieve the purpose of punishment the prevention of special to the offender. 
Prediction of this possibility of implementing additional sentence instead of the main sentence is another phenomenon of liberalization of punishment in the Criminal Code.

In the Criminal Code ten (10) additional penalties, but not all of these penalties are applied in practice, or their implementation is not effective. In many cases, the Court gives only the main sentence unaccompanied by punishment when the nature of the offence committed and wants to do so or provides key sentence in those cases where the conditions for granting just punishment. There are problems and in terms of control in relation to their application in practice.

One of the punishments applied very recently is the removal of the right to run vehicles as punishment given separately or together with the main sentence. Implementation of this sentence has come as results of the large number of accidents that occur because not apply rules of the road.

Also find wide application and other punishments such as seizure of the means of committing the offence and its products, the abolition of the right to undertake leading to juridical persons.

A new sentence was added to complement the list of punishments provided by law 23/2012 is the loss of parental responsibility. This proposal comes given the situation in Albanian legislation, Albania's obligations under the conventions ratified. Of course, the proposal is a logical and valuable, because it is logical to protect the interest of the child by a parent who has abused against him, by not allowing the parent to continue to exercise its rights and obligations as a parent to this child. The problem arises from the fact that the can a criminal court, which considers the parent as the author of a criminal offence, give as punishment loss of parental responsibility? I think this is unlikely, if not impossible for the criminal courts, because the removal or loss of parental responsibility is part of a separate judgment, which is regulated in the rules of the Code of Civil Procedure. The difficulty that confronts a criminal court is that it will have to adjust to the consequences and the need to determine where the child should stay and which is the most convenient arrangement for the child, something a criminal court cannot make it to the end of a criminal trial. The court will punish the offender, then the parent, and with the main sentence, will give punishment. Here ends the work of a criminal court. How to deal with the solution of further consequences, because it may be one or more children? Normally, the Court should investigate for children, for their situation and I think that just criminal process does not give this access. This is not regulated in the criminal procedure code or the law "On Execution of Penal Sentences". Thus will lead to an inability or these kids will fix just in decisions, but will not be adjusted in nature. So no need for changes to the criminal procedure code and the law "On Execution of Criminal Decisions" in order to implement this punishment. So it remains to be seen how it will be implemented in the following sentence.

\section{References}

I. Elezi, (1972) "The leading role of the party in the criminal law of the People's Republic of Albania" (Roli udhëheqes i partisë në të drejtën penale të Republikes Popullore të Shqipërisë), Drejtesia Popullore 1, Tirane, Faculty of Law.

I. Elezi, (1968) "New Criminal Code reflects the main orientations of the party" (Kodi i ri Penal të pasqyrojë orientimet kryesore të parties), Drejtësia Popullore 2, Tirane, Faculty of Law.

I. Elezi et al., (2009) "Commentary of the Criminal Code of the Republic of Albania: The general part" (Komentari i Kodit Penal të Republikës së Shqipërisë: Pjesa e Përgjithshme), Tirane, West Print Publishing House.

F. Gjilani, (2001) "State and right during the regime of Ahmet Zogu: History of state and law in Albania" (Shteti dhe e drejta gjatë regjimit të Ahmet Zogu: Historia e shtetit dhe e se drejtes ne Shqiperi), Tirane, Luarasi Publishing.

V. Hysi, (2012) "Penology" (Penologjia), Tirane, Kristalina-KH Publishing.

S. Kurti, (2014) "The importance of respecting the procedure for the execution of the penal verdict 153". Paper presented at the International Scientific Conference Rule of law in Albania: Challenges and perspectives, Tirana, Albania, 15-16 may 2014.

Criminal Code of the Republic of Albania.

Criminal Procedure Code of the Republic of Albania.

Criminal Code of 1928.

Criminal Code of 1952.

Criminal Code of 1977.

Family Code and legislation on adoption of the Republic of Albania in 2003.

Law nr.8331, dated 04.21.1998 "On the Execution of Penal Sentences" amended. 